\title{
ON THE RELATION BETWEEN THE FORMATION OF ASSIMILATORY PIGMENTS AND THE RATE OF PHOTOSYNTHESIS IN ETIOLATED OAT SEEDLINGS
}

\author{
by \\ G. BLAAUW-JANSEN, J. G. KOMEN, AND J. B. THOMAS* \\ Botanical Institute of the State University, Utrecht, and \\ Biophysical Research Group Utrecht-Delft, under the direction of A. J. KLUYver, Delft, and \\ J. M. W. MiLatz, Utrecht (Netherlands)
}

\section{INTRODUCTION AND PROBLEM}

After exposure to light etiolated plants show a development of chlorophyll a previous to that of $b$ (SEYBold AND EGLE ${ }^{1}$, Goodwin AND OWENS', SMITH ${ }^{3}$ ). The formation of carotenoids is also influenced by light (RUDOLPH', SIMONIS ${ }^{5}$, STROTT). So during pigment formation the concentration of the pigments show independent variations.

It was tempting to examine whether a relation exists between these variations and the rate of photosynthesis. The experiments of WILLSTäTTER AND STOLL ${ }^{7}$ did not show a clear relation but SImonis ${ }^{5}$ concluded from his experiments, that the rate of photosynthesis is probably indeed influenced by the mutual proportions of the various pigments. He exposed etiolated seedlings partly to red and partly to blue light, and determined the rate of photosynthesis afterwards. The light intensity required to establish the same rate of carbon dioxide assimilation in both sets proved to be $10 \%$ higher for the "blue material" than for the "red material". The total chlorophyll concentration was determined chromatographically. Blue light appeared to be less efficient in chlorophyll formation than red light.

As to the descrepancy of views concerning the latter phenomenon, we will restrict ourselves to quoting $\mathrm{F}_{\mathrm{RANK}}{ }^{8}$, who determined the action spectrum (called effectiveness spectrum by the author) of chlorophyll formation. As compared to the red peak, the blue peak proved to be considerably higher, but also much narrower. So the divergence of the results of various authors may be due to differences in transmission of the filters used.

The discrepancy of the results concerning the influence of pigment concentration on photosynthesis may be explained according to GABRIELSEN ${ }^{\circ}$ by the fact that several authors determined the rate of photosynthesis at light saturation, whilst the effect of chlorophyll concentrations is mainly shown with light intensities which are limiting

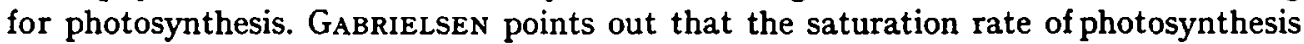
is determined by the available capacity of the BLACKMAN system. Accepting a sufficiently

" This investigation has been made possible by a grant from the Rockefeller Foundation and from the "Stichting voor Zuiver Wetenschappelijk Onderzoek i.o".

References p. 185. 
long life time for the primary photoproducts lower chlorophyll concentrations do not influence the saturation rate; only the light intensity necessary to provide saturation will be enlarged, since absorption is diminished.

If, however, chlorophyll concentrations are extremely low, as is the case during the first hours of illumination of etiolated plants, it is conceivable that GABRIELSEN's theory will no longer hold. For even if we are dealing with long-lived photoproducts, their maximal rate of formation in such a case might be insufficient to saturate the BLACKMAN system, provided its capacity is of the same order of magnitude as in completely green leaves.

In the etiolated seedlings photosynthesis is only very weak, so that variation at low light intensities may not exceed the experimental errors. For this reason we used a light intensity with which saturation occurs in normal green leaves. In this way it is possible to measure the dependence of photosynthesis on extremely low chlorophyll concentrations.

The reader should be aware of the fact that as long as the chlorophyll concentration is low, we are likely to measure in this way the capacity of the primary photochemical reaction, whereas with increasing pigment concentration we shall expect to pass a level corresponding to the available capacity of the Blackman system.

\section{METHODS AND MATERIAL}

After soaking, grains of Avena sativa var. Victorv from Svalöv were laid on moist saw dust. Germination occurred in a conditioned dark room at about $23^{\circ} \mathrm{C}$ and at a relative humidity of $90 \pm 5 \%$. In the experiments 8 days old seedlings were used.

Before illumination the saw dust containers were placed in such a way that the seedlings came into a horizontal position. Underneath the leaves a mirror was adjusted. As light source an incandescent 60 Watt lamp with reflector was used, placed $29 \mathrm{~cm}$ above the seedlings. In this way the light intensity amounted to about 1000 lux. The illumination was varied by changing the duration of exposure. FRANK ${ }^{8}$ rightly criticizes this procedure when applied in experiments dealing with the study of the influence of illumination on pigment formation. Since, however, our experiments had been set up to study the relation between photosynthesis and quantity of the diverse pigments, the way in which the pigments were formed was indifferent.

Immediately after illumination the primary leaves were isolated from their nodes, cut into $\mathrm{I} c \mathrm{~cm}$ pieces and weighed in closed tubes painted black. Photosynthesis was determined by the WarBurg method at light saturation. Each vessel contained pieces of 4 leaves in $5 \mathrm{ml}$ WARBURG buffer solution Nr. 9. The lapse of time between the end of the illumination and the first photosynthesis reading amounted to 40 minutes. The values given are means of three 10 minute readings and computed in $\mathrm{ml} / \mathrm{hour} / 100 \mathrm{mg}$ fresh tissue. During these determinations no increase in the rate of photosynthesis was observed, so no formation of appreciable amounts of pigments appeared to occur. However. always seedlings which had not been used in the photosynthesis experiments were subjected to pigment extraction.

In order to establish physiological conditions as far as possible, the coleoptiles were left attached to the seedlings until illumination was over. So the primary leaves were partly covered by these organs. Pigment formation proved not to be confined to the uncovered area, though it proceeds more rapidly in this region. In order to examine the influence of shadowing by the coleoptiles, increase in chlorophyll content was studied also in objects freed from these organs before illumination. Throughout the experiments only material with a homogeneous appearance has been used (length of the primary leaf $\pm 13 \mathrm{~cm}$, length of the coleoptile $\pm 5 \mathrm{~cm}$ ).

\section{DETERMINATION OF THE PIGMENTS}

The pigments were determined both qualitatively (chromatographically) and quantitatively (with the aid of a spectrophotometer). All manipulations were done in weak green light and their duration did not exceed one hour. One gramme of leaves was ground with cleaned sand and a little $\mathrm{CaCO}_{8}$ in $10 \mathrm{ml}$ acetone during 3 minutes. Three subsequent acetone extractions proved to be sufficient to remove the pigments quantitatively. $20 \mathrm{ml}$ of ether were added to the combined filtered extracts

References p. 285 . 
$(20 \mathrm{ml})$ in a separatory funnel. The liquids were mixed. Upon addition of $40 \mathrm{ml}$ of water the pigmen ts went into the ether. The water-acetone mixture was extracted several times with fresh ether until the latter remained colourless. The ether solution was evaporated to dryness in vacuo. After dissolving the residue in a few drops of benzene, petroleum ether was added up to a volume of $\mathrm{I} \mathrm{ml}$. This solution was used for chromatographical analysis.

The adsorption tube $(12 \times 150 \mathrm{~mm})$ was filled with a mixture of sugar and petroleum ether (cf. STRAIN $\left.{ }^{10}\right)$. The chromatogram was developed with a mixture of benzene and petroleum ether ( $1: 10$ to $\mathrm{r}: 4$ ). The development of the chromatogram lasted $\mathrm{r} 1 / 2$ hour. Scarcely visible amounts of chlorophyll could be detected in ultraviolet light.

For spectrophotometrical determinations the ether extract of 70 leaves was prepared as mentioned above. Instead of evaporating the ether we washed the solution with water to remove the acetone completely. In order to prevent a troublesome flocculation and foam formation we performed the washing by adding water in small droplets to the ether layer and draining off every $15 \mathrm{ml}$. About $300 \mathrm{ml}$ water were used in total. Since the pigments are strongly absorbed by sodium sulfate the solution was dricd by cooling down to $0^{\circ} \mathrm{C}$. Next ether was added up to a known volume, suitable for spectroscopic determinations. Finally the pigment solution was transferred into a cuvette of $0.98 \mathrm{~cm}$ thickness.

The readings were made with the aid of a VAN CiTteri quartz double monochromator (spectral width $25 \AA$ at $6600 \AA$ ), using a vacuum $\mathrm{Cs}-\mathrm{Cs}_{2} \mathrm{O}$ cell in connection with an a.c. amplifier according to MILATZ11.

The amounts of both chlorophyll $a$ and chlorophyll $b$ were calculated from the measured absorption spectrum of the mixture according to the prescription of COMAR 12 . This computation is based on the absorption spectra of both components as determined by ZSCHEILE AND COMAR ${ }^{13}$. In determinations of minute amounts of chlorophyll $b$, a correction was made for the protochlorophyll absorption, using the following data. SEYBOLD ${ }^{14}$, SEYBOLD AND EGLE ${ }^{15}$, and RuDOLPH have found that an absorption peak of protochlorophyll is situated at $6275 \AA$, whilst the absorption is minimal at $6600 \AA$. At $6425 \AA$ a relatively small absorption occurs. Here the absorption at $6425 \AA$ proved to amount to about $1 / \mathrm{s}$ of that at $6275 \AA^{*}$.

The carotenoids were determined as follows. After chlorophyll was determined the ethereal pigment solution was saponified by the addition of alcoholic potassium hydroxide solution (3 ml $\mathrm{CH}_{3} \mathrm{OH}+\mathrm{I} \mathrm{g} \mathrm{KOH}$ ). The mixture was thoroughly shaken every 15 minutes. After one hour Io $\mathrm{ml}$ water were added. The layers formed were separated. The alcohol-water layer was extracted several times with fresh ether until the latter remained colourless. Finally the combined ether extracts were evaporated in vacuo down to a volume of about $0.25 \mathrm{ml}$. Next petroleum ether was added up to I $\mathrm{ml}$.

The carotenes and the xanthophylls were separated chromatographically on a $\mathrm{CaCO}_{3}$ column; the bands were developed in a mixture of petroleum ether and benzene (10:I to $4: 1$ ). The development was continued until the carotenes had passed the column. The total carotene solution was evaporated in vacuo and the pigments were dissolved in ether up to a known volume, suitable for spectrophotometric determination. The absorption was determined at $4500 \AA$.

According to GRIFFITH AND JEFFREY ${ }^{17}$ the average specific absorption coefficent $\varepsilon$ of carotenes amounts to 24 at this wave-length.

The xanthophylls were eluted from the column by means of methanol. The solution was evaporated in vacuo and the residue dissolved in ether as indicated above. The absorption was measured at $44.50 \AA$ using the above-mentioned absorption coefficient.

The various solvents were purified as follows:

ether: distilled, freed from peroxide, stored over sodium;

acetone: distilled from $\mathrm{K}_{2} \mathrm{CO}_{3}$;

benzene: freed from thiophene, stored over sodium;

petroleum ether: treated with $\mathrm{KMnO}_{6}$, distilled at $60-80^{\circ} \mathrm{C}$;

methanol: distilled over $\mathrm{CaO}$.

\section{RESULTS}

Fig. I shows the relation between the duration of the illumination of the seedlings and the rate of photosynthesis (A), the content of chlorophyll $a$ and $b(\mathrm{~B})$, of xanthophylls (C), of carotenes (D), and, finally, the quotient chlorophyll $b /$ chlorophyll $a(E)$.

As appears from Fig. I A non-illuminated seedlings already show a very slight photosynthesis. In these objects the chlorophyll a content could not be evaluated

"The recent, more exact determinations of the protochlorophyll spectrum performed by KosKI AND SMITH ${ }^{16}$ will not appreciably influence the results of our computation.

References $p .185$. 
exactly, neither chromatographically, nor by the spectrophotometric method. The sensitivity of the first method is not sufficient, whilst in the second one the absorption spectrum of protochlorophyll is dominating to such a degree that an exact computation of the $a$ quantity becomes difficult.

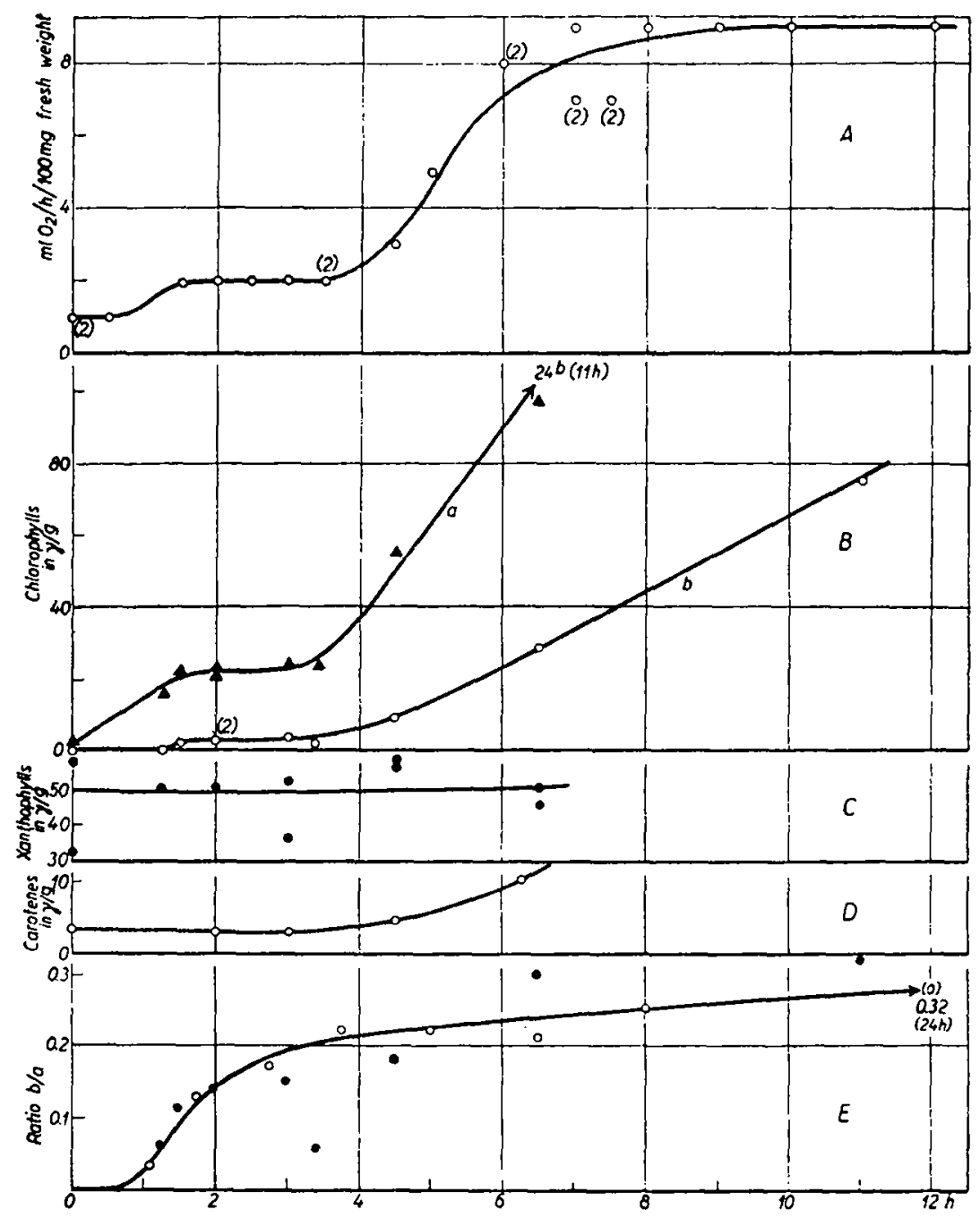

Fig. I. Influence of increasing time of exposure to light on: A : rate of photosynthesis; B: development of chlorophyll $a(A)$ and chlorophyll $b(0) ; C$ : development of xanthophylls; $D$ : development of carotenes; $\mathrm{E}$ : ratio chlorophyll b/chlorophyll $a$. The pigment concentrations are computed per $g$ fresh tissue.

The occurrence of chlorophyll $a$ in non-illuminated seedlings was ascribed to the influence of the dim green light in which they had been handled (and cut into pieces) before transfer to the WARBURG vessels. In absolute darkness no chlorophyll is formed (cf. among others LUBIMEN Ko ${ }^{18}$ ).

When illuminated during 90 minutes both photosynthesis and chlorophyll $a$ content References p. 185 . 
have increased slightly. It is striking to note that these values remain constant up to $3 \frac{1}{2}$ hours of illumination.

The formation of chlorophyll $b$ requires a minimal illumination period of $I 1 / 2$ hours. This pigment is formed only very slowly up to such a period of $3 \frac{1}{2}$ hours.

Upon prolonged illumination the rate of photosynthesis as well as the quantities of both chlorophylls increase rapidly. After about 6 hours of illumination photosynthesis becomes saturated whilst the concentrations of both chlorophylls keep on increasing.

The xanthophylls (Fig. I C) are present already in relatively large quantities in etiolated seedlings. Their increase proved to be independent of light.

However, the formation of the carotenes (Fig. I D), which are present in small amounts in etiolated plants, is accelerated by light.

Fig. I E shows the course of the quotient chlorophyll $b /$ chlorophyll $a$ during pigment formation. A closer examination of this graph will be postponed to the discussion.

\section{DISCUSSION}

In Fig. 2 the chlorophyll a concentration is plotted versus the rate of photo-

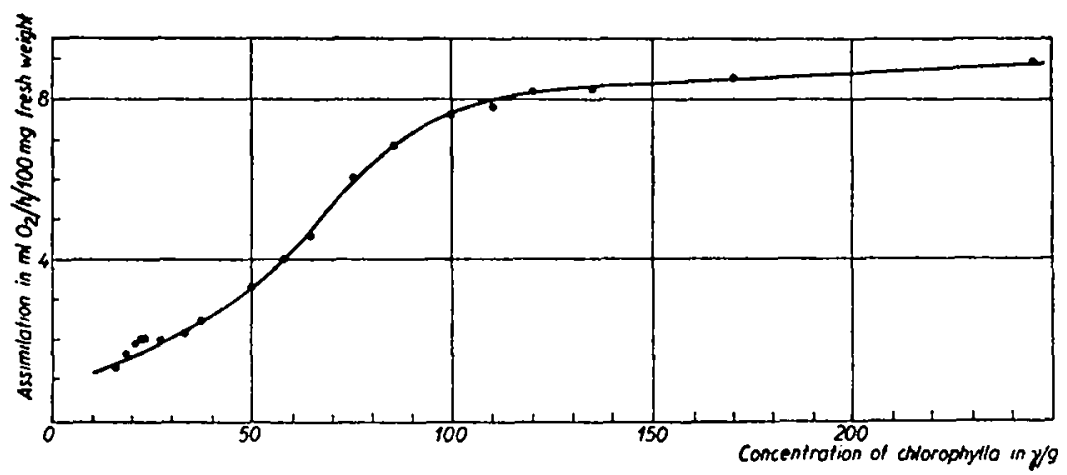

Fig. 2. Relation between rate of photosynthesis and chlorophyll $a$ content

synthesis. The question arises whether the constancy of the rate of photosynthesis and of the pigment concentration between $I \frac{1}{2}$ and $3 \frac{1}{2}$ hours of illumination is significant or not. This phenomenon could be due to the presence of the coleoptiles. In order to examine this possibility the chlorophyll $a$ and chlorophyll $b$ content was studied in seedlings deprived of their coleoptiles before illumination. Fig. 3 shows the results. The chlorophyll content proved to increase in linearity with the duration of the exposure to light,

Fig. 3. Influence of increasing time of exposure to light on the development of chlorophyll $a(\bullet)$ and chlorophyll $b(0)$ in seedlings freed from the coleoptiles

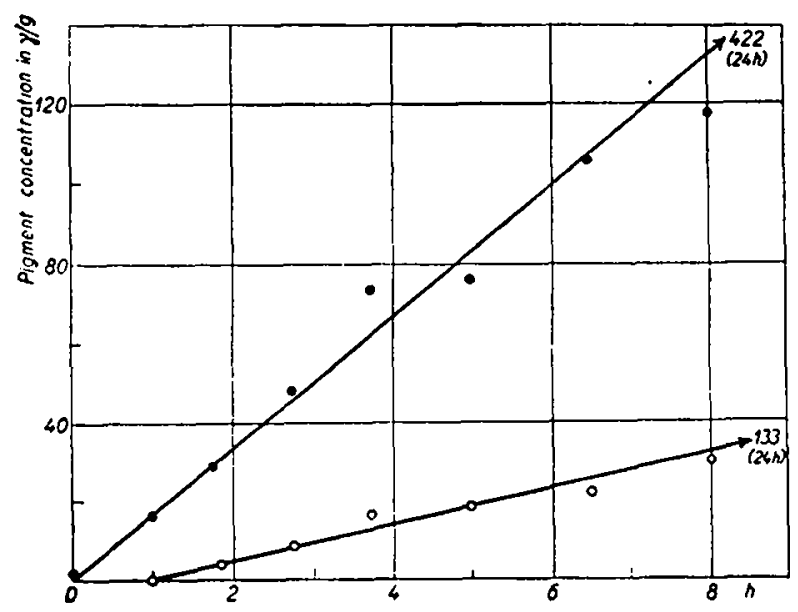


the formation of $a$ preceding that of $b$. Apparently the coleoptiles are at least partly responsible for the temporary constancy of both photosynthesis and pigment concentration. This unexpected deviation might be caused by alterations in the internal conditions of the seedlings, e.g., transport phenomena. This, however, was not further investigated.

The main point is that a simple relation has been shown to exist between photosynthesis and chlorophyll content.

It is interesting to consider the course of the chlorophyll b/chlorophyll a quotient during pigment formation. As is shown in Fig. I $\mathrm{E}$ this quotient increases from the beginning of the chlorophyll $b$ formation until the moment at which the BLACKMAN reaction becomes limiting in photosynthesis. Here the graph of the $b / a$ ratio bends towards the abcissa asymptotically indicating that this ratio approaches its "normal" value. It cannot be decided whether a causal relation between both phenomena exists;

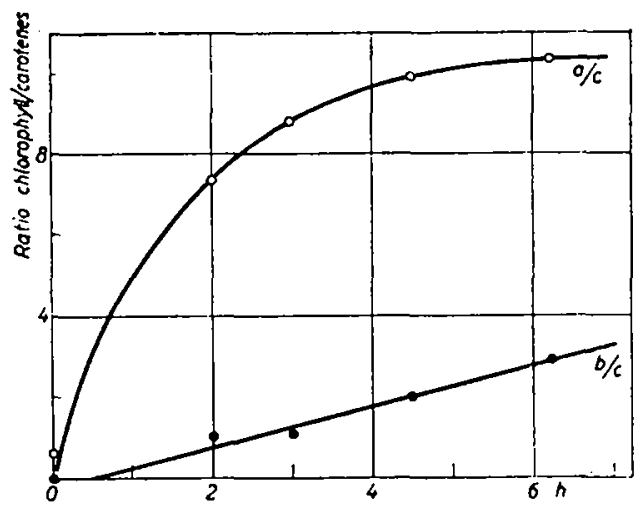

Fig. 4. Variations of the quotients chlorophyll $a /$ carotenes (o) and chlorophyll $b /$ carotenes $(\bullet)$ during increasing time of exposure to light we only mention their coincidence.

As to the formation of carotenes opinions diverge. Euler and Hellströ ${ }^{19}$ denied the occurrence of carotenes in etiolated plants. However, Strain ${ }^{20}$, Barrenscheen, Pany $A N D S_{R B}{ }^{21}$ succeeded in detecting them in nonilluminated tissues. According to STRAIN ${ }^{22}$ this discrepancy of results is due to the analysis of too small quantities of material.

Several authors state that various carotenoids would participate in photosynthesis (for a survey see WAssink ${ }^{23}$ ). So it is interesting to compare the formation of carotenoids in relation to the development of the chlorophylls. Fig. 4 shows the influence of different illumination periods on the quotients chlorophyll $a /$ carotenoids and chlorophyll $b /$ caro-

tenoids. It is worth mentioning that from the moment at which the rate of pigment formation is accelerated (cf. Fig. I) the quotient $a / c$ attains a constant value.

\section{SUMMARY}

The relation between the rate of photosynthesis and the pigment content was studied in seedlings of Avena sativa var. Victory. Etiolated seedlings were illuminated during different periods. Next, the rate of photosynthesis as well as the pigment concentrations were determined in the primary leaves.

The saturation rate of photosynthesis proved to increase with increasing pigment concentrations until the ratio chlorophyll b/chlorophyll $a$ approached its "normal" value. Although the amounts of both pigments still keep on increasing, the saturation rate of photosynthesis remains the same.

In agreement with other authors we could observe that the formation of chlorophyll $a$ starts immediately upon illumination, while $b$ is formed only after a lapse of time.

$\mathrm{Xanthophylls}$ are present in etiolated seedlings in relatively large amounts; their formation is not influenced by light.

Other carotenoids are also present in non-illuminated plants, though in small amounts. Light, however, accelerates their development.

As far as it was studied the quotient chlorophyll a/carotenes remains constant except for very low pigment concentrations.

Rejerences $p .185$. 


\section{RESUME}

Nous avons étudié la vitesse photosynthétique par rapport aux concentrations des pigments dans les plantules d'Avena sativa var. Victory. Les plantules étiolées ont été illuminées pendant des temps différents.

Ensuite la vitesse photosynthétique des feuilles primaires et la concentration des pigments ont été déterminées. La vitesse photosynthétique correspondant a la saturation par rapport à la lumière augmente autant que les concentrations des pigments augmentent, jusqu'a ce que le rapport chloro. phylle $b /$ chlorophylle $a$ approche de sa valeur "normale". Bien que les concentrations des pigments continuent d'augmenter, la valeur de saturation de la photosynthèse reste au même niveau.

D'accord avec d'autres auteurs nous avons constaté que la chlorophylle a est formée immédiatement après le commencement de l'illumination; la production de chlorophylle $b$ ne se manifeste qu'après un certain temps.

Les concentrations des xantophylles dans les plantules étiolées sont assez hautes; l'illumination n'a aucune influence sur leur formation.

Les plantules non-illuminées ne contiennent que peu de carotènes, cependant, la lumière accélère leur formation.

Jusqu'à présent les études ont prouvé que le quotient chlorophylle a/carotènes a une valeur constante sauf pour des concentrations très basses des pigments.

\section{ZUSAMMENFASSUNG}

Die Beziehung zwischen Assimilationsgeschwindigkeit und Farbstoffgehalt wurde in Keimlingen von Avena sativa var. Victory untersucht. Etiolierte Keimlinge wurden belichtet wobei die Zeitdauer variiert wurde. Danach wurde die Assimilationsgeschwindigkeit und Farbstoffkonzentration in den Primärblättern bestimmt.

Es stellte sich heraus, dass der Sättigungswert der Photosynthese so lange mit steigendem Pigmentgehalt ansteigt, bis das Verbältnis Chlorophyll $b / C h l o r o p h y l l ~ a$ seinen "normalen" Wert erreicht. Wenn auch die Pigmentmengen weiter ansteigen, so bleibt dann doch der Photosynthesewert konstant.

In Übereinstemmung mit anderen Untersuchern konnten wir feststellen, dass die Bildung von Chlorophyll $b$ erst nach einiger Zeit einsetzt, während Chlorophyll $a$ sofort nach der Belichtung auftritt.

Xanthophyllbildung ist unabhängig vom Lichte; diese Farbstoffe sind schon in etiolierten Keimlingen in verhältnismässig grossen Mengen vorhanden.

Auch Carotine sind in unbelichteten Pflanzen, wenn auch in kleinen Mengen, anwesend. Licht fördert jedoch ihre Entwicklung.

Soweit es untersucht wurde, zeigt das Verhältnis Chlorophyll a/Carotine einen konstanten Wert, sehr niedrige Pigmentkonzentrationen ausgenommen.

\section{REFERENCES}

1 A. Seybold and K. Egle, Planta, 28 (1938) 87:

2 R. H. Goodwin and O. H. Owens, Plant Physiol., 22 (1947) 197.

3 J. H. C. SmIth, ref. Carnegie Inst. Washington Year B., 46 (1947) 85.

4 A. Rudolph, Planta, 2 I (1934) Io4.

6 W. Simonis, Planta, 29 (1939) i 29.

- A. Strott, Jahrb. wiss. Bot., 86 (1938) r.

7 R. Willstätter AND A. STOLl, Untersuchungen über die Assimilation der Kohlensäure, Berlin r918.

S. R. Frank, J. Gen. Physiol., 29 (1946) I 57.

E. K. Gabrielsen, Physiologia Plantarum, I (1948) 5.

10 H. H. Strain, Chromatographic Adsorption Analysis. Interscience Publishers, New York 1945.

11 J. M. W. Milatz, Thesis, Utrecht 1937.

12 C. L. Comar, Ind. Eng. Chem. Anal. Ed., I 4 (1942) 877.

13 F. I'. Zschrile and C. L. Comar, Bot. Gaz., 102 (1940) 463.

14 A. SEybol.d, Planta, 26 (1937) 712.

15 A. Seybold and K. Egle, Planta, 29 (1939) I 19.

16 V. M. Koski and J. H. C. SMith, $J$. Am. Chem. Soc., 7o (1948) $355^{8}$.

17 R. B. GRIFFith aNd R. N. JefFrey, Ind. Eng. Chem. Anal. Ed., 16 (1944) 438.

18 V. N. Lubimenko, ref. B. M. Duggar, Biological Effects of Radiations II, New York 1936.

$19 \mathrm{H}$. von Euler and H. Hellström, Z. Physiol. Chem., 183 (1929) 177.

20 H. H. Strain, Plant Physiol., I3 (1938) 4 I3.

21 H. K. Barrenscheen, J. Pany, and E. Srb, Biorhem. Z., 310 (1942) 285.

22 H. H. Strain, I.eaf Xunthophvlls. Carnegie Inst. Washington, No. 490 (1938).

${ }^{23}$ F. C. Wassink, Ann. Rev. Biochem., I7 (I94') 559. 